\title{
Construction of Opa-Positive and Opa-Negative Strains of Neisseria meningitidis to Evaluate a Novel Meningococcal Vaccine
}

\author{
Manish Sadarangani ${ }^{1,2 *}$, J. Claire Hoe ${ }^{1}$, Martin J. Callaghan ${ }^{1}$, Claire Jones $^{1}$, Hannah Chan ${ }^{3}$, \\ Katherine Makepeace ${ }^{1}$, Hélène Daniels-Treffandier ${ }^{1}$, Mary E. Deadman ${ }^{1}$, Christopher Bayliss ${ }^{4}$, \\ lan Feavers ${ }^{3}$, Peter van der Ley ${ }^{5}$, Andrew J. Pollard ${ }^{1}$
}

1 Department of Paediatrics, University of Oxford and the NIHR Oxford Biomedical Research Centre, Oxford, United Kingdom, 2 Division of Infectious Diseases, Department of Pediatrics, University of British Columbia and BC Children's Hospital, Vancouver, British Columbia, Canada, 3 Division of Bacteriology, National Institute for Biological Standards and Control, Potters Bar, Hertfordshire, United Kingdom, 4 Department of Genetics, University of Leicester, Leicester, United Kingdom, 5 Department of Vaccinology, National Institute of Public Health and the Environment (RIVM), Bilthoven, The Netherlands

\begin{abstract}
Neisseria meningitidis is a major global pathogen causing invasive disease with a mortality of 5-10\%. Most disease in developed countries is caused by serogroup B infection, against which there is no universal vaccine. Opacity-associated adhesin (Opa) proteins are major meningococcal outer membrane proteins, which have shown recent promise as a potential novel vaccine. Immunisation of mice with different Opa variants elicited high levels of meningococcal-specific bactericidal antibodies, demonstrating proof in principle for this approach. Opa proteins are critical in meningococcal pathogenesis, mediating bacterial adherence to host cells, and modulating human cellular immunity via interactions with $T$ cells and neutrophils, although there are conflicting data regarding their effects on $\mathrm{CD}^{+}{ }^{+} \mathrm{T}$ cells. We constructed Opapositive and Opa-negative meningococcal strains to allow further evaluation of Opa as a vaccine component. All four opa genes from $N$. meningitidis strain $\mathrm{H} 44 / 76$ were sequentially disrupted to construct all possible combinations of $N$. meningitidis strains deficient in one, two, three, or all four opa genes. The transformations demonstrated that homologous recombination of exogenous DNA into the meningococcal chromosome can occur with as little as 80 bp, and that minor sequence differences are permissible. Anti-Opa bactericidal antibody responses following immunisation of mice with recombinant Opa were specific to the Opa variant used in immunisation. No immunomodulatory effects were observed when Opa was contained within meningococcal outer membrane vesicles (OMVs), compared to Opa-negative OMVs. These observations support the incorporation of Opa in meningococcal vaccines.
\end{abstract}

Citation: Sadarangani M, Hoe JC, Callaghan MJ, Jones C, Chan H, et al. (2012) Construction of Opa-Positive and Opa-Negative Strains of Neisseria meningitidis to Evaluate a Novel Meningococcal Vaccine. PLoS ONE 7(12): e51045. doi:10.1371/journal.pone.0051045

Editor: Thomas Rudel, University of Würzburg, Germany

Received May 17, 2012; Accepted October 31, 2012; Published December 12, 2012

Copyright: (C) 2012 Sadarangani et al. This is an open-access article distributed under the terms of the Creative Commons Attribution License, which permits unrestricted use, distribution, and reproduction in any medium, provided the original author and source are credited.

Funding: This study was funded by Action Medical Research, through a Research Training Fellowship awarded to MS (RTF1263), and Meningitis UK and supported by the Oxford Partnership Comprehensive Biomedical Research Centre with funding from the Department of Health's NIHR Biomedical Research Centres funding scheme. The views expressed in this publication are those of the authors and not necessarily those of the Department of Health. The funders had no role in study design, data collection and analysis, decision to publish, or preparation of the manuscript.

Competing Interests: AJP and IF are named inventors on Opa related patents (0428381.8, dated 24/12/2004 and WO2006/067469 A2, dated 22/12/2005). AJP is an advisor to the UK Department of Health's Joint Committee on Vaccines and Immunisation on meningococcal vaccines. AJP conducts clinical trials of meningococcal vaccines on behalf of the University of Oxford and his department has received unrestricted educational grants from vaccine manufacturers (Novartis, GlaxoSmithKline, Pfizer and Sanofi Pasteur) for organisation of educational activities, but he receives no personal payments from them. This does not alter the authors' adherence to all the PLOS ONE policies on sharing data and materials.

*E-mail: manish.sadarangani@paediatrics.ox.ac.uk

\section{Introduction}

Neisseria meningitidis causes up to 500,000 cases of meningitis and septicaemia worldwide annually, with a mortality rate of approximately $10 \%$ [1]. Most cases of disease are caused by 5 of the 13 meningococcal serogroups: A, B, C, Y and W135. Proteinpolysaccharide conjugate vaccines are now available for all of these serogroups except serogroup B, since epitopes of this polysaccharide capsule are cross-reactive with the human neural cell adhesion molecule [2], and it is therefore not immunogenic in humans [3]. Serogroup B organisms are currently the major cause of disease in most temperate countries [4,5,6,7,8]. A number of vaccines based on different combinations of subcapsular antigens are currently in development for the prevention of serogroup B disease [9], including different outer membrane vesicle (OMV) vaccines using genetically modified meningococci $[9,10,11,12]$.

The Opacity-associated (Opa) adhesin proteins are some of the major proteins found in the outer membrane of $\mathcal{N}$. meningitidis and $\mathcal{N}$. gonorrhoeae, which can express up to four or eleven different Opa variants respectively, encoded at loci dispersed throughout the genome $[13,14,15]$. There are at least 338 allelic variants (www. neisseria.org, accessed 17th April 2012) due to sequence variability in three of the four surface-exposed loops $[16,17]$. Opa proteins play a critical role in meningococcal pathogenesis by mediating bacterial adherence to the nasopharynx and modulating human cellular immunity via interactions with $\mathrm{T}$ cells and neutrophils $[18,19]$. Opa proteins are a potential novel vaccine candidate for 
the prevention of meningococcal disease caused by all serogroups, and have the potential to protect against the hyperinvasive isolates which are responsible for most of the disease burden [20,21]. Bactericidal antibodies are currently accepted as the correlate of protection against meningococcal disease, and anti-Opa bactericidal antibodies have been demonstrated in patients following infection with $\mathcal{N}$. meningitidis and in recipients of serogroup B OMV vaccines $[22,23,24,25,26,27,28,29]$. Immunisation of mice with recombinant Opa proteins or Opa-containing liposomes has also elicited the production of high levels of bactericidal antibodies $[21,30]$. One obstacle to human trials of an Opa vaccine is an observation that these proteins might inhibit $\mathrm{CD}^{+} \mathrm{T}$ cell proliferation under certain conditions in vitro, although there are conflicting published data about the validity of this observation $[31,32,33,34,35]$. The potential expression of multiple Opa proteins from any given isolate has made it difficult to study the immunoprotective or immunomodulatory effects of specific Opa proteins expressed on the bacterial surface.

In order to individually assess different Opa variants as potential vaccine candidates, we constructed Opa-positive and Opanegative meningococcal strains, from the same parent strain, expressing different Opa proteins. A library of strains was derived from $\mathcal{N}$. meningitidis strain $\mathrm{H} 44 / 76$ in which one, two, three or four opa genes had been disrupted, for further evaluation of Opa proteins as a potential meningococcal vaccine candidate. These strains were utilised to examine the specificity of the anti-Opa response following immunisation of mice with recombinant Opa protein and Opa-positive or Opa-negative OMVs.

\section{Results}

\section{Construction of $\Delta$ opa plasmids}

Locus-specific $\triangle o p a$ plasmids were designed to facilitate sequential, targeted disruption of the four opa genes (opaA, opaB, opaD and opaf) of $\mathcal{N}$. meningitidis strain H44/76. These $\triangle$ spa plasmids each contained a disrupted opa gene flanked by upstream and downstream sequences specific for the relevant opa locus, with or without an antibiotic resistance cassette (for selection following transformation) (figure 1). However, some of the cloning steps were unsuccessful; it was not possible to construct locus-specific $\triangle o p a B$ plasmids, and insertion of an antibiotic resistance cassette was only possible for the $\Delta o p a f$ plasmid. An alternative strategy was devised based on the finding that the four opa genes of strain H44/76 possess $96 \%$ sequence identity for the $253 \mathrm{bp}$ at the $5^{\prime}$ end and $93 \%$ for the 228 bp at the $3^{\prime}$ end, with $99 \%$ similarity between opaA and opaf, and $97 \%$ between $o p a B$ and $o p a D$ within these regions. Generic $\triangle o p a$ plasmids were therefore constructed, without the flanking locus-specific regions, to enable non-specific disruption of opa genes (figure 1). Locus-specific plasmids all included the suffix -nmb. PGR primers are listed in table 1.

\section{$\Delta$ opaJ plasmids}

The $5^{\prime}$ and $3^{\prime}$ ends of opaf were amplified separately along with adjacent sections of the neighbouring genes nmb0925 and pip, introducing SalI and BamHI or SacII and BamHI restriction sites at the ends of the amplicons. These were cloned separately into pCR2.1-TOPO before being excised with the relevant restriction enzymes and ligated together in the plasmid vector pBluescript II (SK-) to construct pBS- $\Delta$ opaJ-nmb. An erythromycin resistance cassette (EryR) containing erm $C$ was amplified from the plasmid pER2 [36], using primers ery-bamf and ery-bamr to introduce BamHI sites flanking erm C. The resulting amplicon was cloned into pCR2.1-TOPO, excised with BamHI and inserted into the BamHI site of pBS- $\Delta$ opaJ-nmb, resulting in pBS- $\Delta$ opaJ::ery-nmb. $\Delta$ opaf::-

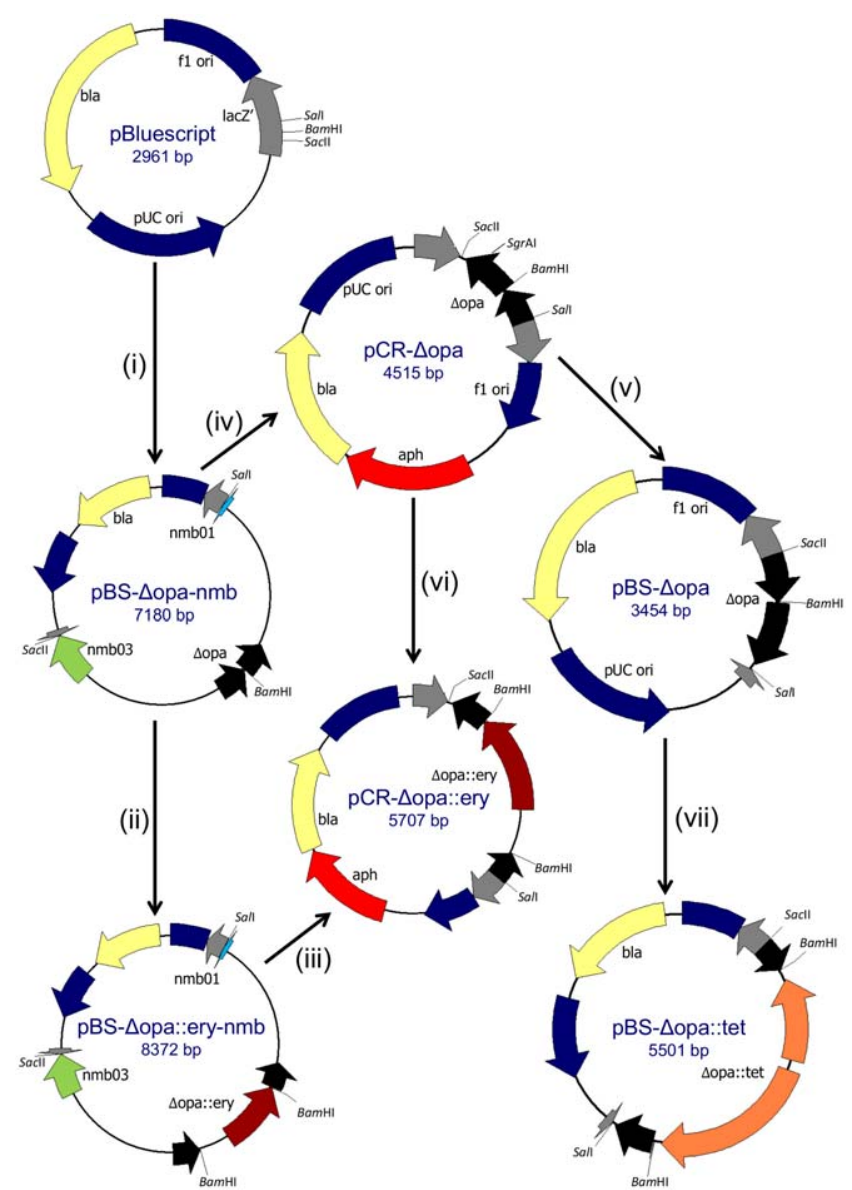

Figure 1. Summary of cloning steps in construction of Lopa plasmids. A general scheme is depicted. Different steps were used for each opa gene, as described below and in the text. (i) The $5^{\prime}$ and $3^{\prime}$ ends of opaA, opaD or opaJ (black) were amplified by PCR (table 1) along with the adjacent locus-specific genes, depicted as nmb01 (blue)

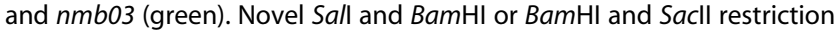
sites were introduced at the ends of the amplicons. Each PCR product was then cloned separately into PCR2.1-TOPO (not shown). The two ends of each opa were excised from the pCR2.1 plasmids and cloned sequentially into pBluescript, resulting in locus-specific plasmids pBS$\Delta$ opaA-nmb, pBS- $\Delta$ opaD-nmb and pBS- $\Delta$ opaJ-nmb. These plasmids therefore contained a modified opa gene, $\Delta$ opa, which contained a $185 \mathrm{bp}$ deletion. (ii) A 1,192 bp BamHl fragment carrying ermC was cloned into pBS- $\Delta$ opaJ-nmb to produce pBS- $\Delta$ opaJ::ery-nmb. (iii) $\Delta o p a j:: e r y$ was amplified from $\mathrm{pBS}-\Delta$ opaJ::ery-nmb using primers OpaFSall and OpaRSacll (table 1), excluding opaJ locus-specific regions. The resulting amplicon was cloned into PCR2.1-TOPO to generate the generic plasmid $\mathrm{pCR}-\triangle \mathrm{opa}$ ::ery. (iv) $\triangle o p a A$ and $\triangle o p a D$ were amplified from their respective $\mathrm{pBS}-\Delta \mathrm{opa}-\mathrm{nmb}$ plasmids using primers OpaFSall and OpaRSacll. Each modified opa was cloned into pCR2.1-TOPO, resulting in the generic plasmids $\mathrm{pCR}-\triangle \mathrm{O} p \mathrm{PA}$ and $\mathrm{pCR}-\triangle \mathrm{OpaD}$. (v) $\triangle O p a A$ and $\triangle O p a D$ were excised from the pCR2.1 plasmids by double digestion with Sall and Sacll and cloned into pBluescript which had been similarly prepared, to create pBS- $\Delta$ opa plasmids. (vi) A 1,194 bp SgrAl fragment carrying erm $C$ was cloned into $\mathrm{pCR}-\triangle \mathrm{O} p \mathrm{PD}$ to produce pBS- $\Delta$ opaD::ery. (vii) A kanamycin (KanR) or tetracycline (TetR) resistance cassette was introduced into $\mathrm{pBS}-\Delta \mathrm{opaD}$, or KanR was introduced into $\mathrm{pBS}-\triangle \mathrm{opaA}$, resulting in generic $\triangle \circ p a$ plasmids containing selectable markers.

doi:10.1371/journal.pone.0051045.g001

ery was amplified from this plasmid using primers OpaFSalI and OpaRSacII to exclude adjacent locus-specific genes. This amplicon contained $\Delta$ opaf::ery and the immediately adjacent opa homologous regions, including a downstream DNA uptake 
Table 1. PCR primers used for amplification of opa genes from N. meningitidis and construction of $\triangle$ opa plasmids.

\begin{tabular}{|c|c|c|c|}
\hline Target gene(s) & Forward primer & Reverse primer & $\begin{array}{l}\text { Product } \\
\text { size (bp) }\end{array}$ \\
\hline $\begin{array}{l}\text { opaA - } \\
\text { nmb0441 }\end{array}$ & $\begin{array}{l}\text { nitF1Salls } \\
\left.\text { (5'-GCACGTGTCGACACAGCATGATTGTCGATCC- } 3^{\prime}\right)\end{array}$ & $\begin{array}{l}\text { 083BamHI } \\
\text { (5'-CTATATGGATCCGCGCGTCGCCTACGGAC-3') }\end{array}$ & 511 \\
\hline $\begin{array}{l}\text { opaA - } \\
\text { nmb0444* }\end{array}$ & $\begin{array}{l}\text { 085-MSBamHI } \\
\left(5^{\prime} \text {-TाTCTGGATCCGGCATAATCTGCCGCTATTC-3') }\right.\end{array}$ & $\begin{array}{l}\text { NMB0444-4Sacll§ } \\
\text { (5'-TGAAGCCCGCGGGTCAGCACATAGTTGACG-3') }\end{array}$ & 2838 \\
\hline $\begin{array}{l}\text { opaB - } \\
\text { nmb1634† }\end{array}$ & $\begin{array}{l}\text { NMB1634-4Sall§ } \\
\text { (5'-GCCGTAGTCGACTTCTTCCGATCCCAACC-3') }\end{array}$ & $\begin{array}{l}\text { 085BamHI } \\
\text { (5'-TITCTGGATCCGGCATAATCTGCCGCTATCC-3') }\end{array}$ & 2556 \\
\hline $\begin{array}{l}\text { opaB - } \\
\text { nmb1637 }\end{array}$ & $\begin{array}{l}\text { 083BamHI } \\
\text { (5'-CTATATGGATCCGCGCGTCGCCTACGGAC-3') }\end{array}$ & $\begin{array}{l}0464 \text { opaBrevSacII \| } \\
\text { (5'-TTACCGCCGCGGAAGGCGAGGTAGGATTGC-3') }\end{array}$ & 941 \\
\hline $\begin{array}{l}\text { opaD - } \\
\text { nmb1464 }\end{array}$ & $\begin{array}{l}\text { NMB1464-3Sall§ } \\
\text { (5'-CAAAAGGTCGACTGCCAAAGCCTGAGATTGC-3') }\end{array}$ & $\begin{array}{l}\text { 083BamHI } \\
\text { (5'-CTATATGGATCCGCGCGTCGCCTACGGAC-3') }\end{array}$ & 1559 \\
\hline $\begin{array}{l}\text { opaD - } \\
\text { ppx: }\end{array}$ & $\begin{array}{l}\text { 085BamHIף } \\
\left(5^{\prime} \text {-TाTCTGGATCCGGCATAATCTGCCGCTATCC-3') }\right.\end{array}$ & $\begin{array}{l}\text { opaDrevdSacll§ } \\
\text { (5'-TाTCGACCGCGGAGGCGGAATGCTTGTGATAG-3') }\end{array}$ & 2671 \\
\hline $\begin{array}{l}\text { opaJ - } \\
\text { nmb0925 }\end{array}$ & $\begin{array}{l}\text { acthR2Sall§ } \\
\text { (5'-GCGACGGTCGACAGGAGCAGTTCGCCTTGAG-3') }\end{array}$ & $\begin{array}{l}\text { 083BamHI } \\
\text { (5'-CTATATGGATCCGCGCGTCGCCTACGGAC-3') }\end{array}$ & 1968 \\
\hline opaJ - pip & $\begin{array}{l}\text { 085-MSBamHI } \\
\left(5^{\prime} \text {-TITCTGGATCCGGCATAATCTGCCGCTATTC-3') }\right.\end{array}$ & $\begin{array}{l}\text { pipSEQRSaCII** } \\
\left(5^{\prime} \text {-CCGGTTCCGCGGATTTTCAGCAATCGGCGCG-3') }\right.\end{array}$ & 2360 \\
\hline $\begin{array}{l}\text { ermc } \\
(\text { EryR) }+\dagger\end{array}$ & $\begin{array}{l}\text { ery-bamfई } \\
\text { (5'-GATCCCGGATCCTGCAGGAATTCGATATCAAGC-3') }\end{array}$ & $\begin{array}{l}\text { ery-bamr§ } \\
\text { (5'-CCGGGCGGATCCTCGAGGTCGACGGTATCG-3') }\end{array}$ & 1210 \\
\hline $\begin{array}{l}\text { ermc } \\
(\text { EryR })+\dagger\end{array}$ & $\begin{array}{l}\text { ery-sgrf§ } \\
\left(5^{\prime} \text {-TGGATCCACCGGTGTGCAGGAATTCGATATCAAGC-3') }\right.\end{array}$ & $\begin{array}{l}\text { ery-sgrr§ } \\
\left(5^{\prime} \text { - TACCGGCACCGGCGTCGAGGTCGACGGTATCG-3') }\right.\end{array}$ & 1214 \\
\hline $\begin{array}{l}\text { tet } A-\operatorname{tet} R \\
(\text { TetR })^{* * *}\end{array}$ & $\begin{array}{l}\text { NmnDUS5§ } \$ \\
\left(5^{\prime}-\text { GGACGATCGATGCCGTCTGAAACCAATACAATGTAGGCTGC-3') }\right.\end{array}$ & $\begin{array}{l}\text { NmnDUS3§ } \\
\left(5^{\prime} \text {-GGACGATCGTTTCAGACGGCATCGAAAAACCTAAAAGAGC- } 3^{\prime}\right)\end{array}$ & 1990 \\
\hline 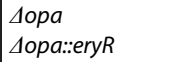 & $\begin{array}{l}\text { OpaFSall§ } \\
\left(5^{\prime} \text { TCCGCGTCGACGGCGGCAAGTGAAGACG-3') }\right.\end{array}$ & $\begin{array}{l}\text { OpaRSacll§ } \\
\text { (5' ATGCCGCCGCGGGGTTCAGACGGCATCG-3') }\end{array}$ & $\begin{array}{l}584 \\
1776\|\| \|\end{array}$ \\
\hline \multicolumn{4}{|c|}{ 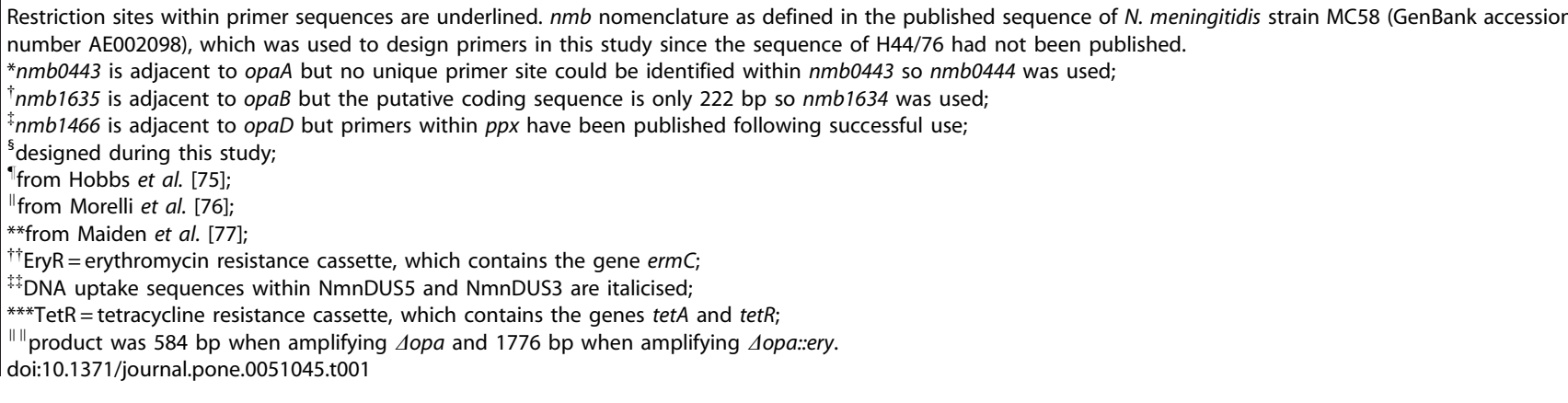 } \\
\hline
\end{tabular}

sequence (DUS), and novel SalI and SacII sites at either end. This was cloned into pCR2.1-TOPO to construct pCR-opaJ::ery.

\section{$\triangle \mathrm{opaD}$ plasmids}

pBS-opaD-nmb was constructed in a similar fashion to pBSopaJ-nmb. $\triangle o p a D$ was amplified from this plasmid using OpaFSalI and OpaRSacII and cloned into pCR2.1-TOPO, resulting in pCR- $\triangle$ opaD. $\triangle o p a D$ was excised using SaII and SacII and ligated into pBluescript, which had been similarly prepared, to create pBS- $\Delta$ opaD. EryR was inserted into pCR- $\Delta$ opaD by amplifying erm $C$ from pER2 using primers ery-sgrf and ery-sgrr, to introduce $\operatorname{Sgr} \mathrm{AI}$ sites flanking erm $C$, before cloning it into the $\operatorname{Sgr} \mathrm{AI}$ site within $o p a D$, to obtain pCR- $\Delta$ opaD::ery. A kanamycin resistance cassette (KanR) was excised from pUC4-kan (GenBank accession number X06404) using BamHI. A tetracycline resistance cassette (TetR) was constructed by excising a HindIII-SalI fragment from pHVT1 [37], which was cloned into a plic2A vector and amplified by PCR using primers NmnDUS5 and NmnDUS3 (table 1). This reduced the size of TetR by several hundred base pairs, and introduced novel Pst $\mathrm{I}$ sites and neisserial DNA uptake sequences. This amplicon was cloned into a TA vector, excised with Pst $\mathrm{I}$ and inserted into pUC4-kan which had been similarly prepared, thus replacing KanR with TetR to produce pUC4NmDUS. pBS$\Delta$ opaD::kan and pBS- $\Delta$ opaD::tet were constructed by insertion of either KanR or TetR, respectively, into the BamHI site of pBS$\Delta$ opaD.

\section{$\Delta$ opaA plasmids}

pBS- $\Delta$ opaA-nmb was constructed as described for pBS- $\Delta$ opaJnmb. pBS- $\Delta$ opaA and pBS- $\Delta$ opaA::kan were derived in a similar fashion to the equivalent $\triangle o p a D$ plasmids.

\section{Construction of opa-deficient meningococci}

$\mathcal{N}$. meningitidis strain $\mathrm{H} 44 / 76$ was sequentially transformed with different $\Delta$ opa plasmids to create a library of 15 new opa-deficient strains, each theoretically able to express different combinations of the four Opa proteins (figure 2 and figure 3). Plasmids containing different antibiotic resistance cassettes were used to enable selection after each disruption. Plasmids containing $\triangle o p a A$ or $\Delta$ opaf were able to target both of these genes and those containing $\triangle o p a D$ disrupted $o p a B$ and $o p a D$. To disrupt all four opa genes with only three selectable markers, one of the antibiotic resistance 
cassettes had to be removed to be re-introduced at a different opa locus. Strain M011 was obtained by transformation of M009 using pBS- $\Delta$ opaJ-nmb to replace $\Delta$ opaf::kan with $\Delta$ opaf. A single transformed clone was obtained after screening 10,000 colonies following transformation. This strain was then used to produce two additional strains with $\mathrm{KanR}$ introduced within opaA or opaD and in which opaf remained disrupted. KanR only conferred kanamycin resistance in $\mathcal{N}$. meningitidis if inserted into opa in the same orientation as the opa gene.

pBS- $\Delta$ opaA::kan resulted in integration of $\Delta o p a A:: k a n$ into the opaA locus on 70/73 (96\%) occasions, and into opaf following other transformations. Similarly, pCR- $\Delta$ opaJ::ery only targeted opa $f$ and opaA, disrupting opaf 53/68 times (78\%). A total of 81 clones were identified where generic plasmids based on opaD had undergone homologous recombination. This occurred at the opaD locus on 67 occasions (83\%), at the opaB locus 10 times (12\%), and at the opaA locus in four clones $(5 \%)$. Four of the events where integration occurred into the opaD locus were single crossover events, with both KanR and TetR being present at the same locus. Although this has been described [38,39], it is not thought to be a common occurrence in $\mathcal{N}$. meningitidis. All other successful transformations were confirmed by PCR to be double crossover events. Transformation rates varied between $10^{-5}$ and $10^{-7}$, consistent with previous studies [39,40].

\section{DNA sequence analysis of $\Delta$ opa genes}

Nucleotide sequence analysis was performed on multiple loci where recombination occurred between two different opa genes, one located on the plasmid and one on the chromosome. Crossover events were observed throughout the homologous flanking regions, including within the first 81 bp of homology, close to the site of the primer used to amplify the $o p a$ genes, and also within $80 \mathrm{bp}$ of the antibiotic resistance cassette (figure $\mathrm{S} 1$ ). Data from opa pentanucleotide coding repeat (CR) sequences, contained within the $5^{\prime}$ end of the Opa open reading frame, revealed that the length of the $\mathrm{CR}$ tracts had altered in some opa genes during construction of the strain library (table S1). Based on the length of the CR tract, the mature Opa protein should only be expressed on the bacterial surface if the number of $\mathrm{CR}$ sequences is a multiple of 3 . Therefore, the wild type strain used in this study is not expected to express any Opa proteins, whereas M001 should express both OpaA and OpaD. Only OpaD is predicted to be expressed by M002, M005 and M007. None of the other strains are expected to express any Opa proteins, based on the nucleotide sequence, although they would have the capacity for differential expression of Opa by phase variation (PV) at opa loci which had not been disrupted.

\section{Characterisation of Opa-positive and Opa-negative meningococci}

H44/76, M001, M002 and M014 were characterised further and used to provide additional information on the immunogenicity of Opa in the mouse model. Immunodot-blotting of ethanol-fixed bacteria using mAbs 15-1-P5.5 and MN20E12.70 confirmed the expected Opa phenotype based on DNA sequencing data, with expression of OpaD for M001 and M002 and OpaA from M001 only (figure S2). SDS-PAGE and immunoblotting of OMVs produced from these strains confirmed Opa expression consistent with the results of DNA sequence analysis and immunodotblotting (figure S2). Protein profiles of other major surfaceexpressed proteins were similar between strains, and based on immunoblotting with specific monoclonal antibodies there was no effect on the expression of PorA, PorB, RmpM or factor $\mathrm{H}$ binding

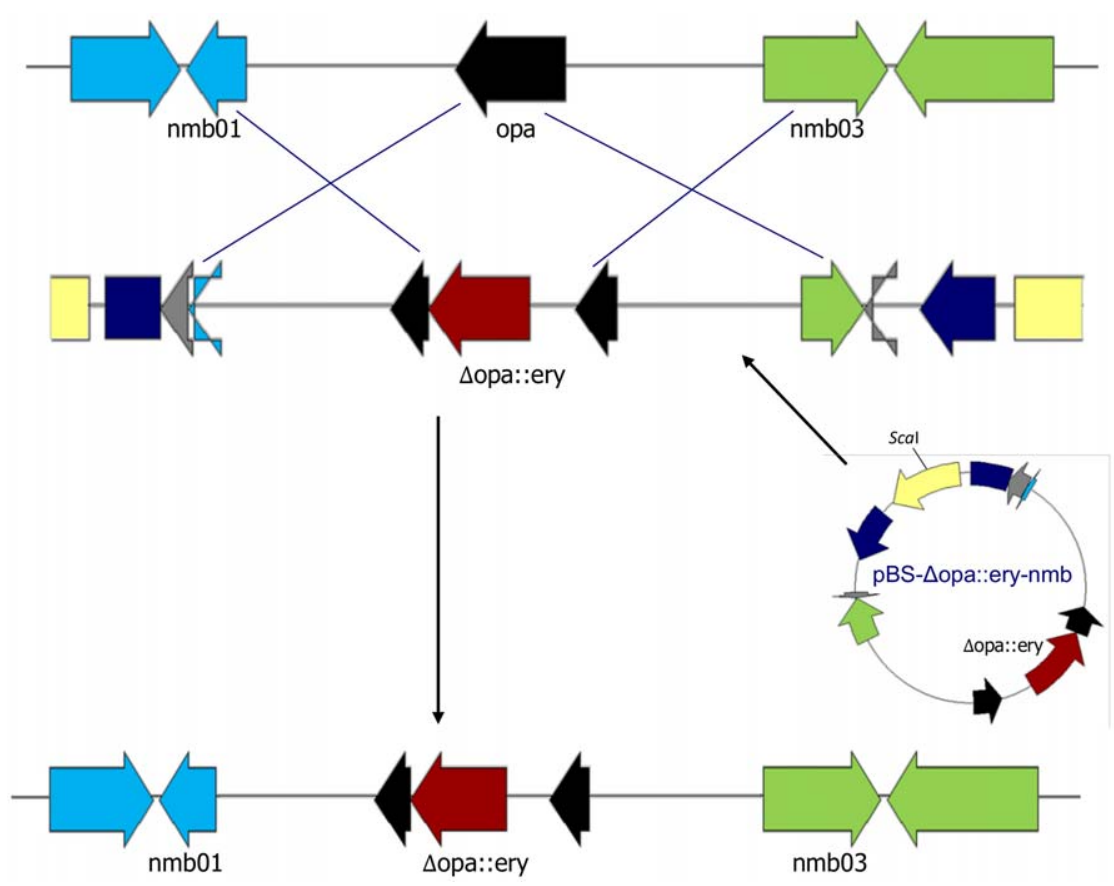

Figure 2. Homologous recombination in $\mathbf{N}$. meningitidis. The plasmid pBS- $\Delta$ opa::ery-nmb contains sequences identical to the $5^{\prime}$ and $3^{\prime}$ ends of opa and adjacent locus-specific sequences flanking an erythromycin resistance cassette, EryR. Crossover events between chromosomal and plasmid DNA are illustrated using linearised plasmid. A double crossover event between homologous regions on the plasmid and chromosome allow EryR to be stably inserted into the chromosome at the opa locus. Generic plasmids containing $\Delta$ opa without locus-specific regions are able to target multiple opa genes for homologous recombination.

doi:10.1371/journal.pone.0051045.g002 


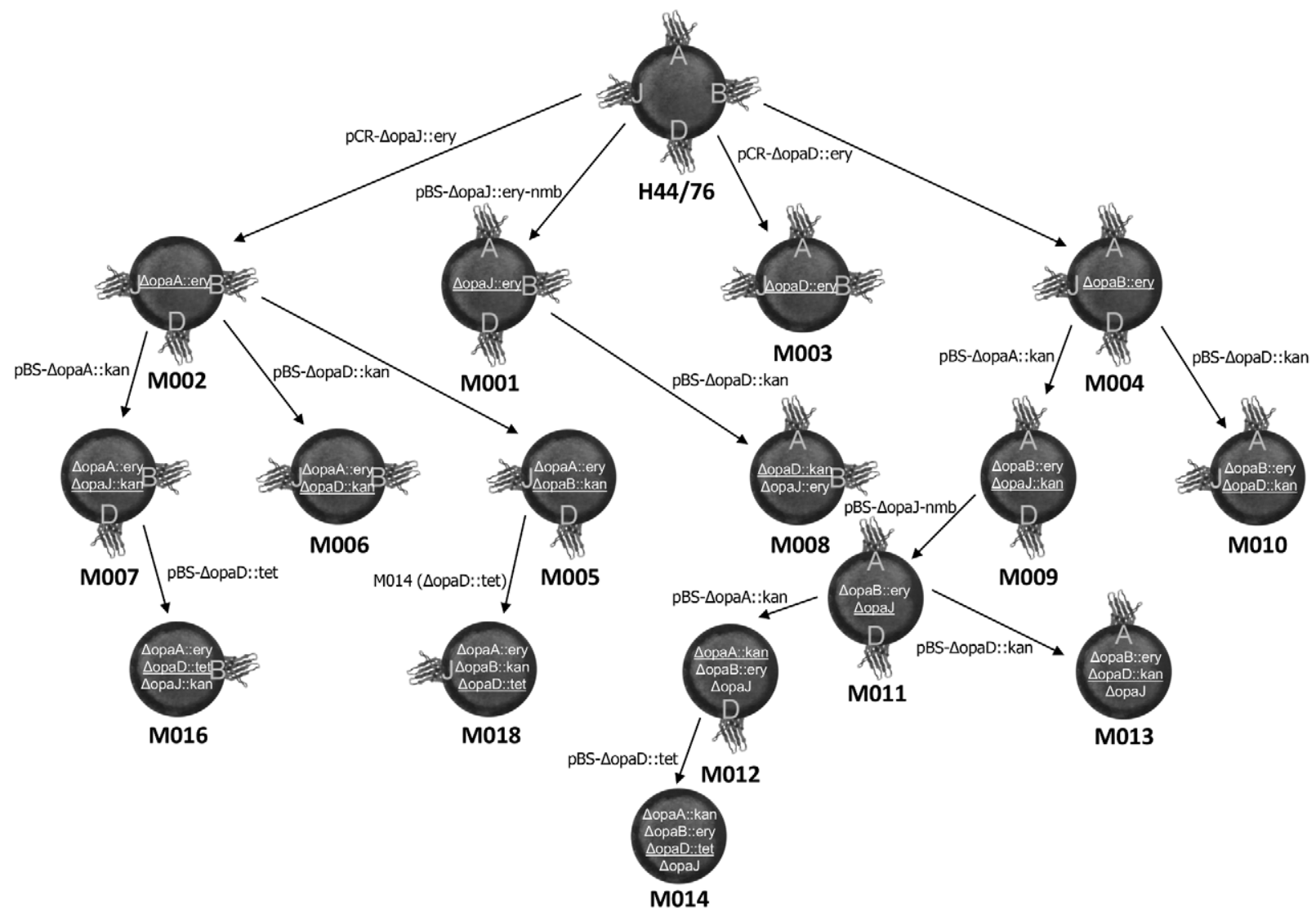

Figure 3. Summary of Opa-deficient mutant meningococci constructed from parent strain H44/76. The plasmid used for each transformation and possible Opa expression of each new strain is indicated, as well as the gene disruptions that have been introduced. For each strain the underlined disruption is the one introduced by the most recent transformation. All possible opa combinations were created, including four single opa-deficient strains, six double opa-deficient strains, four triple opa-deficient strains, and an opa-negative strain. doi:10.1371/journal.pone.0051045.g003

protein (fHbp) following manipulation of Opa expression (figure S3).

Bactericidal antibody responses following immunisation of mice with recombinant Opa proteins and Opa-positive and Opa-negative OMVs

The immunogenicity of recombinant forms of OpaA and OpaD from H44/76 were tested using the selected Opa-positive and Opa-negative strains as target strains in the serum bactericidal antibody (SBA) assay. The recombinant proteins resulted in titres of 1:256 when the target strain expressed the same Opa variant used for immunisation (table 2). SBA titres of $<1: 4$ were observed when the target strain in the SBA assay did not express the Opa variant used for immunisation. Immunisation of mice with any of the four OMVs elicited a bactericidal response against all four target strains, demonstrating little difference between the SBA titres (table 2), with a titre of 1:2048 for most sera against the majority of target strains.

\section{Discussion}

This is the first description of the construction of a library of opadeficient meningococci from a single parent strain, enabling further evaluation of Opa proteins as a potential novel meningococcal vaccine, including investigation of their immunomodulatory effects. This study has also demonstrated significant, specific bactericidal anti-Opa responses following murine immunisation, supporting the pursuit of Opa as a potential vaccine candidate. These strains will be a valuable tool in the assessment of the role of Opa proteins in the pathogenesis of neisserial infection. They will also allow investigation of different Opa variants from the same parent strain to identify any similarities and differences in their functions, and investigate their underlying molecular basis.

Sera from mice immunised with OpaA or OpaD from strain $\mathrm{H} 44$ /76 were only bactericidal when the same Opa was expressed on the surface of the target strain in the SBA assay. Although previous studies have demonstrated that Opa proteins elicit bactericidal antibodies in mice, the Opa-positive and Opanegative strains constructed in this study enabled an accurate assessment of specificity of the anti-Opa SBA response for the first time. Opa cross-reactive antibodies have previously been found following immunisation of mice, and additional investigations utilising a larger panel of Opa variants is required to fully explore the occurrence of any cross-reactivity. This would ideally include study of both mouse and human sera in those who have either received Opa-containing vaccines (including OMVs) or following invasive disease or meningococcal carriage. SBA titres following immunisation with recombinant proteins were between 4- and 16fold lower than following OMV immunisations, which may be expected given that OMVs contain a large number of antigens, including the immunodominant PorA $[24,41,42]$. This is also the likely explanation for the similarity of responses following immunisation with Opa-positive or Opa-negative OMVs, with the inclusion of Opa not conferring either advantage or 
Table 2. Serum bactericidal antibody titres of pooled murine sera against 4 target strains, following immunisation with recombinant OpaA and OpaD, and Opa-positive and Opa-negative OMVs.

\begin{tabular}{|c|c|c|c|c|c|}
\hline \multicolumn{2}{|c|}{ Antigen used for immunisation } & \multicolumn{4}{|c|}{ Target strain in SBA assay (Opa phenotype) } \\
\hline & & H44/76 (Opa-) & M014 (Opa-) & M002 (OpaD+) & M001 (OpaA+ OpaD+) \\
\hline \multirow[t]{2}{*}{ Recombinant protein } & OpaA & $<1: 4$ & $<1: 4$ & $<1: 4$ & 1:256 \\
\hline & OpaD & $<1: 4$ & $<1: 4$ & 1:256 & 1:256 \\
\hline \multirow[t]{4}{*}{$\begin{array}{l}\text { OMV } \\
\text { (Opa phenotype) }\end{array}$} & $\begin{array}{l}\text { H44/76 } \\
(\mathrm{Opa}-)\end{array}$ & 1:4096 & 1:2048 & 1:2048 & 1:2048 \\
\hline & $\begin{array}{l}\text { Mo14 } \\
(\mathrm{Opa}-)\end{array}$ & $1: 2048$ & 1:2048 & $1: 2048$ & 1:1024 \\
\hline & $\begin{array}{l}\text { M002 } \\
\text { (OpaD+) }\end{array}$ & $1: 2048$ & $1: 2048$ & $1: 2048$ & $1: 2048$ \\
\hline & $\begin{array}{l}\text { M001 } \\
(\mathrm{OpaA}+\mathrm{OpaD}+)\end{array}$ & $1: 2048$ & 1:1024 & $1: 2048$ & $1: 2048$ \\
\hline
\end{tabular}

Titres represent highest dilution at which there was $50 \%$ bacterial survival. Immunisation with recombinant Opa elicited bactericidal antibodies in mice if the same Opa variant was expressed by the target strain in the SBA assay, with a titre of 1:256 in all cases. Immunisation with any of the OMVs elicited high levels of bactericidal antibodies in mice against all strains in the SBA assay, with titres between 1:1024 and 1:4096.

doi:10.1371/journal.pone.0051045.t002

disadvantage with respect to SBA response. However, given the lack of bactericidal activity demonstrated against strains not expressing the same Opa, it is likely that all of the SBA activity observed after protein immunisation was Opa-mediated, providing further support for pursuing Opa as a vaccine candidate. Importantly, the expression of Opa within the OMVs did not lead to any inhibition of the SBA response as has been found in some in vitro studies $[34,35]$, although these effects may not necessarily be apparent in mice due to differences between the human and mouse CEACAM repertoire.

Inclusion of Opa proteins in future vaccines will require good quality epidemiological data to identify common Opa variants in circulation for inclusion in the vaccine. This would ideally include additional information on cross-reactivity of the bactericidal response following immunisation and $\mathrm{Opa} \mathrm{PV}$, which would influence the potential effectiveness of any Opa-containing vaccine. The lack of Opa expression in some strains constructed in this study which retained wild-type opa genes highlights the challenge that $\mathrm{PV}$ poses in developing $\mathrm{Opa}$ as a vaccine candidate. This would appear to suggest that four Opa proteins are required in a vaccine to ensure coverage against a single strain, in order to circumvent the problem of PV. However, bactericidal epitopes for anti-Opa antibodies have been described in two of the four surface-exposed loops containing hypervariable $(\mathrm{HV})$ regions [17], and there is limited diversity of these $\mathrm{HV}$ regions among opa genes from hyperinvasive meningococcal isolates [43]. This lends credence to the possibility of providing broad coverage with a small number of Opa variants, despite the occurrence of PV. The importance of Opa to adhesion of meningococci to epithelial cells in the nasopharynx as the precursor to invasive disease mean it is unlikely that no Opa proteins would be expressed within a population of colonising organisms and provides the additional potential that an Opa vaccine might have activity against colonisation through induction of anti-adhesion antibody. No effect of anti-Opa antibodies (from post-mouse immunisation serum or using anti-Opa mAbs) on adhesion was demonstrated in this study using encapsulated bacteria (data not shown) [44,45], and although Opa-mediated adhesion of apparently fully encapsulated meningococci to epithelial cells has been demonstrated $[46,47,48]$, such interactions occur most effectively with acapsulate organisms [49,50], which may represent a significant proportion of meningococci in the nasopharynx $[51,52]$.

DNA sequence analysis following transformation of meningococci revealed that homologous recombination of exogenous DNA can occur with just $80 \mathrm{bp}$ of homology in the flanking region. $\mathcal{N}$. meningitidis is a naturally transformable bacterial species, having the ability to take up extracellular DNA efficiently, and then incorporate it into the chromosome by homologous recombination [53]. This mechanism can be manipulated in vitro to modify expression of specific proteins, and has been utilised recently in the development of several meningococcal vaccines to delete, overexpress or modify surface components and therefore increase the immunogenicity of OMVs derived from these strains $[9,10,11,12]$. However, the minimum requirement for sequence homology has not been clearly defined, although most studies suggest $500 \mathrm{bp}-$ $1,000 \mathrm{bp}$ is required either side of the selectable marker to enable efficient recombination [39,54,55]. Successful transformation has been achieved with 280-290 bp of homology [38,56] and studies of $\mathcal{N}$. gonorrhoeae have reported unpublished observations that recombination can occur with as little as 100 bp of homology, and that minor modifications in the flanking sequence are permissible $[57,58]$. This study provides clear evidence that only $80 \mathrm{bp}$ is sufficient to enable homologous recombination to occur. Even with this relatively small amount of flanking sequence, minor differences were tolerated during the recombination process, although it is much more likely to occur if there is $100 \%$ sequence identity, as demonstrated by the higher rates of recombination at the same opa locus as that carried on the plasmid.

There are currently a limited number of selectable markers available for use in Neisseria, and this study highlights some important factors to optimise performance of these markers and cloning methods. We found that for KanR, the orientation must be the same as the target gene to obtain the resistance phenotype in $\mathcal{N}$. meningitidis [59], although either orientation will confer kanamycin resistance in E. coli. For EryR or TetR, insertion can be in either orientation, which makes these markers easier to use for genetic manipulation of meningococci. Additional unpublished observations from our laboratory have shown that the concentration of kanamycin required in selective media following meningococcal transformation is strain dependent. The data also suggest that removal of a selectable marker is a feasible strategy for the 
manipulation of meningococcal DNA, when efficiency of transformation and recombination is high. This increases the number of genes which can be altered in a single isolate, but a nonantibiotic marker which is easily selectable when it is inserted or removed would greatly facilitate construction of mutant strains, either for the development of new vaccines or investigation of the biology of the organism. This would also ideally involve production of strains which are able to constitutively express different phase variable proteins. Construction of a strain which constitutively expresses Opa has been described for an opa gene of $\mathcal{N}$. gonorrhoeae [60], but this has a number of inherent difficulties, including the presence of a repeat sequence of variable length within the open reading frame, a previous finding that high-level expression of Opa within E. coli was toxic to the host cells [60] and the requirement for high fidelity at each stage of DNA manipulation.

Our library of opa-deficient strains will allow further assessment of Opa as a potential vaccine candidate against meningococcal disease caused by all serogroups. These mutants have a potential use to further investigate the immunomodulatory effects of Opa, in order to identify the most immunogenic variants for use in a future meningococcal vaccine. In addition it will be possible to further investigate the role of Opa proteins during adhesion and invasion, including differences between Opa variants and the effects of expression of different combinations of Opa proteins on the bacterial surface. We have demonstrated that transformation of $\mathcal{N}$. meningitidis is possible with very short regions of homology between plasmid and chromosomal DNA. Such shorter fragments of DNA should be easier to manipulate during cloning, so this finding will ease the construction of genetically modified meningococci in the attempt to develop a broadly protective meningococcal vaccine. These mutants demonstrate there is a significant and specific antiOpa bactericidal antibody response following murine immunisation with recombinant protein, and no inhibition of the response when Opa is contained within OMVs supporting further investigation of Opa as a component of future meningococcal vaccines.

\section{Materials and Methods}

\section{Ethics Statement}

Animal studies were conducted according to the UK Home Office regulations and were approved by the local ethics committee at the National Institute for Biological Standards and Control (Home Office Project Licence Number 80/2157). Samples were obtained following terminal general anaesthesia and all efforts were made to minimise suffering.

\section{Bacterial strains and growth conditions}

Escherichia coli was grown in Luria-Bertani (LB) media at $37^{\circ} \mathrm{C}$ for 16-18 hours, with shaking at $220 \mathrm{rpm}$ for broth cultures. $\mathcal{N}$. meningitidis was grown on brain heart infusion (BHI) agar (Merck, Darmstadt, Germany) supplemented with Levinthal's base $10 \%$ $\mathrm{v} / \mathrm{v})$ at $37^{\circ} \mathrm{C}$ in a humidified $5 \% \mathrm{CO}_{2}$ atmosphere for $16-$ 18 hours. Selective media was supplemented with ampicillin $(100 \mu \mathrm{g} / \mathrm{ml})$, kanamycin $(100 \mu \mathrm{g} / \mathrm{ml})$, erythromycin $(300 \mu \mathrm{g} / \mathrm{ml}$ for $E$. coli and $5 \mu \mathrm{g} / \mathrm{ml}$ for $\mathcal{N}$. meningitidis $)$ or tetracycline $(12 \mu \mathrm{g} / \mathrm{ml}$ for $E$. coli and $2 \mu \mathrm{g} / \mathrm{ml}$ for $\mathcal{N}$. meningitidis) (Sigma-Aldrich, Gillingham, UK).

\section{Transformation of Escherichia coli and Neisseria meningitidis}

Chemically competent $E$. coli $\mathrm{DH} 5 \alpha$ were prepared using calcium chloride $[61,62]$ and transformation of $E$. coli for the propagation of plasmids was performed using standard methods [62]. Transformed cells were plated onto selective LB agar and incubated at $37^{\circ} \mathrm{C}$ for $16-18$ hours, or 36-40 hours when selecting for erythromycin resistance. $\mathcal{N}$. meningitidis was transformed using the spot transformation technique [57]. Briefly, $10 \mu \mathrm{l}$ (approximately $10^{8}$ colony forming units [cfu]) of bacterial suspension from overnight growth was incubated with approximately $1 \mu \mathrm{g}$ of linearised or supercoiled plasmid DNA or chromosomal DNA and plated over a $1-2 \mathrm{~cm}$ diameter region on BHI agar. Reactions were incubated at $37^{\circ} \mathrm{C}, 5 \% \mathrm{CO}_{2}$ for $4-$ 8 hours before bacteria were plated onto selective BHI agar and incubated for a further 16-18 hours (36-40 hours for the introduction of erythromycin resistance). When transforming $\mathcal{N}$. meningitidis to remove an antibiotic resistance cassette, transformation reactions were plated onto non-selective $\mathrm{BHI}$ agar to achieve 500-1,000 cfu per plate before incubation. After 16-18 hours, a nitrocellulose membrane (pore size $0.45 \mu \mathrm{m}$ ) was used to transfer colonies to selective BHI agar plates. After 16-18 hours paired plates were visually screened to identify colonies which were present on non-selective media only. Colonies were re-grown on both selective and non-selective media to confirm loss of antibiotic resistance.

\section{Construction of meningococcal outer membrane vesicles}

Bacteria were grown on $\mathrm{BHI}$ agar at $37^{\circ} \mathrm{C}, 5 \% \mathrm{CO}_{2}$ for 16 18 hours. A few individual colonies were picked and resuspended in 200-1000 $\mu \mathrm{l}$ of PBS, before plating 25-50 $\mu \mathrm{l}$ of this suspension onto BHI agar. OMVs were produced from this suspension as previously described [63] with the exception that thiomersal was excluded from all buffers.

\section{Characterisation of bacteria and outer membrane vesicles}

Bacteria and OMVs were initially characterised using anti-Opa mAbs 15-1-P5.5 and MN20E12.70 [64]. There was some crossreactivity of the mAbs between the Opa variants found in $\mathrm{H} 44 / 76$, with 15-1-P5.5 recognising OpaA and OpaJ, and the target epitope for MN20E12.70 being present in OpaB and OpaD. Expression of other proteins was detected using anti-PorA P1.7 mAb MN14C11.6 [65], anti-PorB P3.15 mAb 2-1-P15 [65], antiRmpM mAb 173,G-1 [66] and anti-fHbp variant 1 mAb JAR4 [67]. Antibody binding was detected using alkaline phosphataseconjugated anti-mouse IgG and BCIP/NBT (Sigma-Aldrich). Immunodot-blotting of meningococcal cell suspensions was performed as previously described after bacteria had been fixed in $70 \%$ ethanol [21]. Total protein concentrations of OMVs were determined using a modified Lowry assay. Protein profiles were analysed by SDS-PAGE and immunoblotting was carried out using standard methods to confirm expression of Opa and other proteins [68].

\section{Recombinant DNA methods}

Plasmid DNA was isolated from $E$. coli using the QIAprep Miniprep kit (Qiagen, Crawley, UK) before being screened by polymerase chain reaction (PCR) using the universal primers M13 forward (5'-GTAAAACGACGGGCAG-3') and M13 reverse (5'CAGGAAACAGCTATGAC-3') and restriction enzyme digestion. Chromosomal DNA from $\mathcal{N}$. meningitidis was isolated using the QIAamp DNA Mini kit (Qiagen). Following transformation, the identity of each new meningococcal transformant was confirmed by growth on selective media and analysis by PGR (table 3). PGR was carried out using primers at a concentration of $0.2 \mu \mathrm{M}$ per reaction (Sigma-Aldrich). Each reaction contained 1.25 units Taq 
DNA Polymerase (Qiagen) and $200 \mu \mathrm{M}$ each of dATP, dCTP, dGTP and dTTP in a total volume of $50 \mu \mathrm{l}$. PGR conditions were: initial denaturation at $95^{\circ} \mathrm{C}$ for 5 minutes; 30 cycles of denaturation at $95^{\circ} \mathrm{C}$ for 30 seconds, annealing at $55^{\circ} \mathrm{C}$ for 30 seconds, extension at $68^{\circ} \mathrm{C}$ for 3 minutes; final elongation at $68^{\circ} \mathrm{C}$ for $3-$ 10 minutes. TA cloning was performed using the vector pCR2.1TOPO (Invitrogen, Paisley, UK) according to the manufacturer's instructions. Ligation reactions were performed using standard methods [62].

\section{DNA sequencing}

Dye-terminator DNA sequencing was used following amplification of opa genes by PCR. Amplicons were purified by precipitation with polyethylene glycol $8000(20 \% \mathrm{w} / \mathrm{v}) / \mathrm{NaCl}$ $(2.5 \mathrm{M})$, followed by centrifugation at $2,750 \times g$ for 1 hour at $4^{\circ} \mathrm{C}$ and washing with ethanol $(70 \%)$. Sequencing reactions contained $1.3 \mathrm{pmol}$ oligonucelotide primer (Sigma-Aldrich) and $0.5 \mu \mathrm{l}$ BigDye Terminator Ready Reaction Mix (Applied Biosystems, Paisley, UK) in a total of $10 \mu$ l. The following conditions were used: 30 cycles of $95^{\circ} \mathrm{C}$ for 10 seconds, $50^{\circ} \mathrm{C}$ for 6 seconds and $60^{\circ} \mathrm{C}$ for 2 minutes. Sequencing primers were O85 (5'-GGCATAATCTGCGGCTATCG-3') [69] and OpaFwdII (5'-TATATTGTGTTGAAACATGG-3'), which was based on O3510 [20]. Extension products were purified by precipitation with ethanol $(100 \%) /$ sodium acetate $(115 \mathrm{mM}, \mathrm{pH} 4.6)$ and centrifugation as above. Labelled extension products were separated by capillary electrophoresis on a $3730 \times 1$ DNA Analyzer (Applied Biosystems) at the Department of Zoology Sequencing Facility, University of Oxford. Sequence trace chromatograms were assembled into consensus sequences using the Staden sequence analysis package [70], using Gap4 shotgun assembly. Sequences were aligned using Clustal X (version 2.0) [71] and visualised with GeneDoc (version 2.7.000) [72]. No new sequence data were generated in this study.

\section{Preparation of recombinant Opa proteins}

Refolded recombinant Opa proteins were produced in E. coli inclusion bodies from the pET22b(+)/ opa plasmids as previously described [21,73] with an additional purification step. Ion exchange chromatography was performed following heparin affinity chromatography using a Resource $\mathrm{S}$ column (GE Healthcare, Buckinghamshire, UK) equilibrated in sodium acetate (50 mM, pH 4.6) containing LDAO (0.1\%). Opa protein was then eluted by application of a gradient from 0 to $1 \mathrm{M} \mathrm{NaCl}$. Fractions containing Opa proteins were pooled, dialysed into PBS containing $\operatorname{LDAO}(0.1 \%)$ and stored at $-20^{\circ} \mathrm{C}$.

\section{Immunisation of mice}

Groups of ten 6-7 week old female BALB/c mice (Charles River, Margate, UK) were immunised subcutaneously with $5 \mu \mathrm{g}$ of recombinant Opa protein or OMVs (2.5 $\mu \mathrm{g}$ total protein) on days 0, 21 and 35. The oil-in-water emulsion Sigma Adjuvant System (Sigma-Aldrich), in a total volume of $2.4 \mathrm{ml}$ of antigen solution per vial, was reconstituted with the antigen on the day of immunisation. Blood was collected by cardiac puncture on day 42 and serum separated by centrifugation at $16,100 \times g$ for 10 minutes.

Table 3. PCR primers used for screening opa genes following transformation of Neisseria meningitidis.

\begin{tabular}{|c|c|c|c|c|c|c|c|}
\hline \multirow[t]{2}{*}{ Target of PCR } & \multirow[t]{2}{*}{ Forward primer } & \multirow[t]{2}{*}{ Reverse primer } & \multicolumn{5}{|c|}{ Product size (bp) } \\
\hline & & & opa (wt*) & opa::ery & opa::kan & opa::tet & sopa \\
\hline EryR & ery-bamf & ery-bamr & - & 1210 & - & - & - \\
\hline KanR & kan-if & kan-ir & - & - & 963 & - & - \\
\hline TetR & tetF & tetR & - & - & - & 1603 & - \\
\hline opaA & nitF1Sall & NMB0444-4Sacll & 3510 & 4523 & 4595 & 5378 & - \\
\hline opaB & NMB1634-4Sall & 0464 opaBrevSacll & 3676 & 4673 & 4743 & - & - \\
\hline opaD & NMB1464-7Sall & NMB1466-0Sacll & 2703 & 3700 & 3770 & 4553 & - \\
\hline opaJ & acthR2Sall & pipSEQRSacll & 4489 & 5502 & 5574 & - & 4310 \\
\hline opaA::ery & nitF1Sall & ery-bamf & - & 1703 & - & - & - \\
\hline opaA::kan & nitF1Sall & kan-5-out & - & - & 887 & - & - \\
\hline opaB::ery & ery-bamf & 0464 opaBrevSacll & - & 1950 & - & - & - \\
\hline opaB::kan & NMB1634-4Sall & kan-3-out & - & - & 2881 & - & - \\
\hline opaD::ery & ery-bamr & NMB1466-0Sacll & - & 2459 & - & - & - \\
\hline opaD::kan & kan-3-out & NMB1466-0Sacll & - & - & 1407 & - & - \\
\hline opaD::tet & tetR & NMB1466-0Sacll & - & - & - & 2923 & - \\
\hline opaJ::ery & ery-bamr & pipSEQRSacll & - & 3552 & - & - & - \\
\hline opaJ::kan & kan-3-out & pipSEQRSacll & - & - & 2685 & - & - \\
\hline$\Delta o p a J$ & acthR2Sall & opaFSall & 2370 & - & - & - & 2191 \\
\hline
\end{tabular}

Following each transformation, three PCR reactions were carried out at each opa locus to confirm recombination. The antibiotic resistance cassette was amplified using internal primers to confirm it had inserted into the genome. The antibiotic resistance cassette was amplified with one internal primer and one primer within a locusspecific gene adjacent to opa to confirm insertion had occurred within the target opa gene. Finally, the entire opa locus was amplified using primers in adjacent genes to confirm a double crossover event had occurred.

*wt = wild-type. Primer sequences were: kan-if, 5'-AGCCATATTCAACGGGAAAC-3'; kan-ir, 5'-TTTGCTTTGCCACGGAAC-3'; tetF, 5'-TTGATGCTCTTGATCTTCC-3'; tetR, 5'TAACAGCAAACAGTAATGG-3'; NMB1464-7Sall, 5'-TGCAGAGTCGACGGCATCAACACCCATGC-3'; NMB1466-0Sacll, 5'-CCGCCTCCGCGGTTATGTTGTGCGACCAGTCC-3'; kan5-out, 5'-TCAAAAATATGGTATTGATAATCC-3'; kan-3-out, 5'-TGTAACATCATTGGCAACGC-3'. Other primer sequences are described in table 1.

doi:10.1371/journal.pone.0051045.t003 


\section{Serum bactericidal assay}

Bactericidal activity in mouse serum pooled within each immunisation group was quantified by SBA based on a published method [74]. Briefly, pooled murine sera was heated at $56^{\circ} \mathrm{C}$ for 30 minutes to deactivate endogenous complement and then diluted to give a range from $1: 4$ to $1: 1024$. Diluted sera was incubated with mid-log phase meningococci (125 cfu) and baby rabbit complement (lot number 11330, PelFreez Biologicals, Rogers, AR) at a final concentration of $25 \%$ (v/v). Reactions were incubated for 60 minutes at $37^{\circ} \mathrm{C}$ in a humidified $5 \% \mathrm{CO}_{2}$ atmosphere. A sample of each reaction was spread by tilting onto BHI agar plates, which were incubated overnight. The bactericidal antibody titre was reported as the reciprocal of the highest serum dilution at which $50 \%$ bacterial survival was observed. Each serum sample was analysed in duplicate against each target strain. When SBA titres were too high to be determined, additional assays were performed with dilution of sera to $1: 16,384$.

\section{Supporting Information}

Figure S1 Sequence alignment of wild type opaB, plasmid AopaD::ery, AopaB::ery from strain M004 and MopaB::ery from strain M005. Strains M004 and M005 were constructed by disruption of $о p a B$ with a plasmid based on $о p a D$, containing either $\triangle o p a D:: e r y$ (strain M004) or $\triangle$ opaD::kan (strain M005). For strain M004, homologous recombination had to occur between positions 89 (position of PCR primer used to clone $\triangle o p a D$ into the plasmid) and 712 ( $\operatorname{Sgr} \mathrm{AI}$ site where $\mathrm{erm} C$ was inserted) both regions are highlighted in black. Differences between the chromosomal $o p a B$ and plasmid $\triangle o p a D$ (highlighted in grey) reveal that the $\triangle o p a B$ locus of strain M004 was identical to the wild type until at least position 633, so recombination occurred between positions 633 and 712. Similarly, the $\triangle o p a B$ locus of strain M005 was identical to the plasmid $\triangle o p a D$ at all positions where differences existed, so recombination occurred between positions 89 and 170. Other notable features are the longer CR tract within $\triangle o p a D$ and deletion of a 197 bp-fragment compared to wild type opaB.

(TIF)

Figure S2 Characterisation of Opa-positive and Opanegative bacteria and OMVs. (a) and (b) Immunodotblot of ethanol-fixed bacteria. (c) and (d) SDS-PAGE and immunoblotting of OMVs. (a) Immunodot-blot layout; (b) Immunodot-blotting using mAbs 15-1-P5.5 (anti-OpaA) and MN20E12.70 (anti-OpaD) confirmed expected Opa phenotype of all four strains as predicted by the DNA sequence data. 1 and

\section{References}

1. World Health Organization (1998) Control of epidemic meningococcal disease. WHO practical guidelines. 2nd edition. Geneva, Switzerland: World Health Organization.

2. Finne J, Leinonen M, Makela PH (1983) Antigenic similarities between brain components and bacteria causing meningitis. Implications for vaccine development and pathogenesis. Lancet 2: 355-357.

3. Wyle FA, Artenstein MS, Brandt BL, Tramont EC, Kasper DL, et al. (1972) Immunologic response of man to group B meningococcal polysaccharide vaccines. J Infect Dis 126: 514-521.

4. Gray SJ, Trotter CL, Ramsay ME, Guiver M, Fox AJ, et al. (2006) Epidemiology of meningococcal disease in England and Wales 1993/94 to 2003/04: contribution and experiences of the Meningococcal Reference Unit. J Med Microbiol 55: 887-896.

5. Ramsay M, Fox A (2007) EU-IBIS Network. Invasive Neisseria meningitidis in Europe 2006. London: Health Protection Agency.

6. Baethgen LF, Weidlich L, Moraes C, Klein C, Nunes LS, et al. (2008) Epidemiology of meningococcal disease in southern Brazil from 1995 to 2003 , and molecular characterization of Neisseria meningitidis using multilocus sequence typing. Trop Med Int Health 13: 31-40.
$5=\mathrm{H} 44 / 76 ; 2$ and $6=\mathrm{M} 014 ; 3$ and $7=\mathrm{M} 001 ; 4$ and $8=\mathrm{M} 002$; $1-4=$ blotting with $\mathrm{mAb} 15-1-\mathrm{P} 5.5 ; 5-8=$ blotting with $\mathrm{mAb}$ MN20E12.70. (c) SDS-PAGE of OMVs. Lanes A and F=lowrange molecular weight standards (Bio-Rad, Hemel Hempstead, $\mathrm{UK}$; lane $\mathrm{B}=\mathrm{H} 44 / 76$; lane $\mathrm{C}=\mathrm{M} 014$; lane $\mathrm{D}=\mathrm{M} 001$; lane $\mathrm{E}=\mathrm{M} 002$. The black arrow highlights an additional band present in strains M001 and M002 only, which was confirmed as representing Opa based on immunoblotting. Profiles of all other proteins were comparable between strains (figure S3). (d) Immunoblotting confirmed expression of OpaA and OpaD in the relevant strains, as well as low level expression of Opa in the wild-type strain, and no Opa expression in the Opa-negative strain. Lanes $1-4=$ blotting with mAb 15-1-P5.5; lanes 5$8=$ blotting with mAb MN20E12.70. Lanes 1 and $5=\mathrm{H} 44 / 76$; lanes 2 and $6=\mathrm{M} 014$; lanes 3 and $7=\mathrm{M} 001$; lanes 4 and $8=\mathrm{M} 002 . \quad \mathrm{H} 44 / 76=$ wild-type; $\quad$ M014= Opa-negative; $\mathrm{M} 001=\mathrm{OpaA}+\mathrm{OpaD}+; \mathrm{M} 002=\mathrm{OpaD}+$

(TIF)

Figure S3 Expression of non-Opa major meningococcal outer membrane proteins by immunoblotting of OMVs. Immunoblotting with specific mAbs confirmed that expression of PorA, PorB, RmpM and fHbp was comparable in strains H44/76, M014, M001 and M002.

(TIF)

Table S1 Number of coding repeat (GR) sequences in the $\mathbf{N}$-terminal region of each opa gene in the wild-type and opa-deficient mutant strains constructed. Opa protein expression should occur if the number of CR sequences is a multiple of three since the mature polypeptide is translated inframe. Genes where Opa protein expression would be expected based on the nucleotide sequence are shown in bold. No Opa expression would be expected for other opa genes. $\Delta$ : opa gene disrupted, so protein expression not possible; *Change in number of CRs from parent strain.

(DOG)

\section{Acknowledgments}

AJP is a Jenner Institute Investigator and James Martin Senior Fellow.

\section{Author Contributions}

Conceived and designed the experiments: MS JCH MJC CJ MED CB PvdL AJP. Performed the experiments: MS JCH CJ HC KM HDT MED CB. Analyzed the data: MS. Contributed reagents/materials/analysis tools: MS JCH CJ HC MED CB IF PvdL. Wrote the paper: MS.

7. Rosenstein NE, Perkins BA, Stephens DS, Popovic T, Hughes JM (2001) Meningococcal disease. N Engl J Med 344: 1378-1388.

8. Baker MG, Martin DR, Kieft CE, Lennon D (2001) A 10-year serogroup B meningococcal disease epidemic in New Zealand: descriptive epidemiology, 1991-2000. J Paediatr Child Health 37: S13-19.

9. Sadarangani M, Pollard AJ (2010) Serogroup B meningococcal vaccines-an unfinished story. Lancet Infect Dis 10: 112-124.

10. Bonvehi P, Boutriau D, Casellas J, Weynants V, Feron C, et al. (2010) Three doses of an experimental detoxified L3-derived lipooligosaccharide meningococcal vaccine offer good safety but low immunogenicity in healthy young adults. Clin Vaccine Immunol 17: 1460-1466.

11. Keiser PB, Biggs-Cicatelli S, Moran EE, Schmiel DH, Pinto VB, et al. (2011) A phase 1 study of a meningococcal native outer membrane vesicle vaccine made from a group B strain with deleted lpxL1 and synX, over-expressed factor $\mathrm{H}$ binding protein, two PorAs and stabilized OpcA expression. Vaccine 29: 14131420 .

12. Keiser PB, Gibbs BT, Coster TS, Moran EE, Stoddard MB, et al. (2010) A phase 1 study of a group $\mathrm{B}$ meningococcal native outer membrane vesicle vaccine made from a strain with deleted lpxL2 and synX and stable expression of opcA. Vaccine 28: 6970-6976. 
13. Parkhill J, Achtman M, James KD, Bentley SD, Churcher C, et al. (2000) Complete DNA sequence of a serogroup A strain of Neisseria meningitidis Z2491. Nature 404: 502-506.

14. Tettelin H, Saunders NJ, Heidelberg J, Jeffries AC, Nelson KE, et al. (2000) Complete genome sequence of Neisseria meningitidis serogroup B strain MC58. Science 287: 1809-1815.

15. Bhat KS, Gibbs CP, Barrera O, Morrison SG, Jahnig F, et al. (1991) The opacity proteins of Neisseria gonorrhoeae strain MS11 are encoded by a family of 11 complete genes. Mol Microbiol 5: 1889-1901.

16. de Jonge MI, Bos MP, Hamstra HJ, Jiskoot W, van Ulsen P, et al. (2002) Conformational analysis of opacity proteins from Neisseria meningitidis. Eur J Biochem 269: 5215-5223.

17. Malorny B, Morelli G, Kusecek B, Kolberg J, Achtman M (1998) Sequence diversity, predicted two-dimensional protein structure, and epitope mapping of neisserial Opa proteins. J Bacteriol 180: 1323-1330.

18. Gray-Owen SD (2003) Neisserial Opa proteins: impact on colonization, dissemination and immunity. Scand J Infect Dis 35: 614-618.

19. Virji M, Makepeace K, Ferguson DJ, Achtman M, Moxon ER (1993) Meningococcal Opa and Opc proteins: their role in colonization and invasion of human epithelial and endothelial cells. Mol Microbiol 10: 499-510.

20. Callaghan MJ, Jolley KA, Maiden MC (2006) Opacity-associated adhesin repertoire in hyperinvasive Neisseria meningitidis. Infect Immun 74: 5085-5094.

21. Callaghan MJ, Lewis S, Sadarangani M, Bailey SE, Chan H, et al. (2011) Potential of Recombinant Opa Proteins as Vaccine Candidates against Hyperinvasive Meningococci. Infect Immun 79: 2810-2818.

22. Mandrell RE, Zollinger WD (1989) Human immune response to meningococcal outer membrane protein epitopes after natural infection or vaccination. Infect Immun 57: 1590-1598.

23. Sjursen H, Wedege E, Rosenqvist E, Naess A, Halstensen A, et al. (1990) IgG subclass antibodies to serogroup B meningococcal outer membrane antigens following infection and vaccination. Apmis 98: 1061-1069.

24. Milagres LG, Gorla MC, Sacchi CT, Rodrigues MM (1998) Specificity of bactericidal antibody response to serogroup B meningococcal strains in Brazilian children after immunization with an outer membrane vaccine. Infect Immun 66: 4755-4761.

25. Bjune G, Hoiby EA, Gronnesby JK, Arnesen O, Fredriksen JH, et al. (1991) Effect of outer membrane vesicle vaccine against group $\mathrm{B}$ meningococcal disease in Norway. Lancet 338: 1093-1096.

26. Sierra GV, Campa HC, Varcacel NM, Garcia IL, Izquierdo PL, et al. (1991) Vaccine against group B Neisseria meningitidis: protection trial and mass vaccination results in Cuba. NIPH Ann 14: 195-207; discussion 208-110.

27. de Moraes JC, Perkins BA, Camargo MC, Hidalgo NT, Barbosa HA, et al. (1992) Protective efficacy of a serogroup B meningococcal vaccine in Sao Paulo, Brazil. Lancet 340: 1074-1078.

28. Noronha CP, Struchiner CJ, Halloran ME (1995) Assessment of the direct effectiveness of BC meningococcal vaccine in Rio de Janeiro, Brazil: a casecontrol study. Int J Epidemiol 24: 1050-1057.

29. Oster P, Lennon D, O'Hallahan J, Mulholland K, Reid S, et al. (2005) MeNZB: a safe and highly immunogenic tailor-made vaccine against the New Zealand Neisseria meningitidis serogroup B disease epidemic strain. Vaccine 23: 21912196.

30. de Jonge MI, Hamstra HJ, Jiskoot W, Roholl P, Williams NA, et al. (2004) Intranasal immunisation of mice with liposomes containing recombinant meningococcal OpaB and OpaJ proteins. Vaccine 22: 4021-4028.

31. Wiertz EJ, Delvig A, Donders EM, Brugghe HF, van Unen LM, et al. (1996) Tcell responses to outer membrane proteins of Neisseria meningitidis: comparative study of the Opa, Opc, and PorA proteins. Infect Immun 64: 298-304.

32. Wiertz EJ, van Gaans-van den Brink JA, Schreuder GM, Termijtelen AA, Hoogerhout $\mathrm{P}$, et al. (1991) T cell recognition of Neisseria meningitidis class 1 outer membrane proteins. Identification of $\mathrm{T}$ cell epitopes with selected synthetic peptides and determination of HLA restriction elements. J Immunol 147: 2012 2018.

33. Youssef AR, van der Flier M, Estevao S, Hartwig NG, van der Ley P, et al. (2009) Opat and Opa- isolates of Neisseria meningitidis and Neisseria gonorrhoeae induce sustained proliferative responses in human CD4+ T cells. Infect Immun 77: 5170-5180.

34. Lee HS, Boulton IC, Reddin K, Wong H, Halliwell D, et al. (2007) Neisserial outer membrane vesicles bind the coinhibitory receptor carcinoembryonic antigen-related cellular adhesion molecule 1 and suppress CD4+ T lymphocyte function. Infect Immun 75: 4449-4455.

35. Boulton IC, Gray-Owen SD (2002) Neisserial binding to CEACAM1 arrests the activation and proliferation of CD4+ T lymphocytes. Nat Immunol 3: 229-236.

36. van der Voort ER, van der Ley P, van der Biezen J, George S, Tunnela O, et al. (1996) Specificity of human bactericidal antibodies against PorA P1.7,16 induced with a hexavalent meningococcal outer membrane vesicle vaccine. Infect Immun 64: 2745-2751.

37. Danner DB, Pifer ML (1982) Plasmid cloning vectors resistant to ampicillin and tetracycline which can replicate in both E. coli and Haemophilus cells. Gene 18: 101-105.

38. Fisseha M, Chen P, Brandt B, Kijek T, Moran E, et al. (2005) Characterization of native outer membrane vesicles from lpxL mutant strains of Neisseria meningitidis for use in parenteral vaccination. Infect Immun 73: 4070-4080.
39. Hamilton HL, Schwartz KJ, Dillard JP (2001) Insertion-duplication mutagenesis of neisseria: use in characterization of DNA transfer genes in the gonococcal genetic island. J Bacteriol 183: 4718-4726.

40. Catlin BW (1960) Transformation of Neisseria meningitidis by deoxyribonucleates from cells and from culture slime. J Bacteriol 79: 579-590.

41. Martin DR, Ruijne N, McCallum L, O'Hallahan J, Oster P (2006) The VR2 epitope on the PorA P1.7-2,4 protein is the major target for the immune response elicited by the strain-specific group B meningococcal vaccine MeNZB. Clin Vaccine Immunol 13: 486-491.

42. Rosenqvist E, Hoiby EA, Wedege E, Bryn K, Kolberg J, et al. (1995) Human antibody responses to meningococcal outer membrane antigens after three doses of the Norwegian group B meningococcal vaccine. Infect Immun 63: 46424652.

43. Callaghan MJ, Buckee C, McCarthy ND, Ibarz Pavon AB, Jolley KA, et al. (2008) Opa protein repertoires of disease-causing and carried meningococci. J Clin Microbiol 46: 3033-3041.

44. Virji M, Kayhty H, Ferguson DJ, Alexandrescu C, Heckels JE, et al. (1991) The role of pili in the interactions of pathogenic Neisseria with cultured human endothelial cells. Mol Microbiol 5: 1831-1841.

45. Gomez-Duarte OG, Dehio M, Guzman CA, Chhatwal GS, Dehio C, et al. (1997) Binding of vitronectin to opa-expressing Neisseria gonorrhoeae mediates invasion of HeLa cells. Infect Immun 65: 3857-3866.

46. Virji M, Watt SM, Barker S, Makepeace K, Doyonnas R (1996) The N-domain of the human CD66a adhesion molecule is a target for Opa proteins of Neisseria meningitidis and Neisseria gonorrhoeae. Mol Microbiol 22: 929-939.

47. Bradley CJ, Griffiths NJ, Rowe HA, Heyderman RS, Virji M (2005) Critical determinants of the interactions of capsule-expressing Neisseria meningitidis with host cells: the role of receptor density in increased cellular targeting via the outer membrane Opa proteins. Cell Microbiol 7: 1490-1503.

48. Rowe HA, Griffiths NJ, Hill DJ, Virji M (2007) Co-ordinate action of bacterial adhesins and human carcinoembryonic antigen receptors in enhanced cellular invasion by capsulate serum resistant Neisseria meningitidis. Cell Microbiol 9: 154-168.

49. Virji M, Makepeace K, Ferguson DJ, Watt SM (1996) Carcinoembryonic antigens (CD66) on epithelial cells and neutrophils are receptors for Opa proteins of pathogenic neisseriae. Mol Microbiol 22: 941-950.

50. Virji M, Evans D, Hadfield A, Grunert F, Teixeira AM, et al. (1999) Critical determinants of host receptor targeting by Neisseria meningitidis and Neisseria gonorrhoeae: identification of Opa adhesiotopes on the N-domain of CD66 molecules. Mol Microbiol 34: 538-551.

51. Weber MV, Claus H, Maiden MC, Frosch M, Vogel U (2006) Genetic mechanisms for loss of encapsulation in polysialyltransferase-gene-positive meningococci isolated from healthy carriers. Int J Med Microbiol 296: 475-484.

52. Cartwright KA, Stuart JM, Jones DM, Noah ND (1987) The Stonehouse survey: nasopharyngeal carriage of meningococci and Neisseria lactamica. Epidemiol Infect 99: 591-601.

53. Lorenz MG, Wackernagel W (1994) Bacterial gene transfer by natural genetic transformation in the environment. Microbiol Rev 58: 563-602.

54. Van Der Ley P, Poolman JT (1992) Construction of a multivalent meningococcal vaccine strain based on the class 1 outer membrane protein. Infect Immun 60: 3156-3161.

55. Warren MJ, Roddam LF, Power PM, Terry TD, Jennings MP (2004) Analysis of the role of pglI in pilin glycosylation of Neisseria meningitidis. FEMS Immunol Med Microbiol 41: 43-50.

56. Weynants V, Denoel P, Devos N, Janssens D, Feron C, et al. (2009) Genetically modified L3,7 and L2 lipooligosaccharides from Neisseria meningitidis serogroup B confer a broad cross-bactericidal response. Infect Immun 77 : $2084-2093$.

57. Gunn JS, Stein DC (1996) Use of a non-selective transformation technique to construct a multiply restriction/modification-deficient mutant of Neisseria gonorrhoeae. Mol Gen Genet 251: 509-517.

58. Stein DC (1989) Introduction of cloned genes into Neisseria gonorrhoeae. Clin Microbiol Rev 2 Suppl: S146-149.

59. van der Ley P, van der Biezen J, Poolman JT (1995) Construction of Neisseria meningitidis strains carrying multiple chromosomal copies of the porA gene for use in the production of a multivalent outer membrane vesicle vaccine. Vaccine 13: 401-407.

60. Kupsch EM, Knepper B, Kuroki T, Heuer I, Meyer TF (1993) Variable opacity (Opa) outer membrane proteins account for the cell tropisms displayed by Neisseria gonorrhoeae for human leukocytes and epithelial cells. Embo J 12: 641-650.

61. Cohen SN, Chang AC, Hsu L (1972) Nonchromosomal antibiotic resistance in bacteria: genetic transformation of Escherichia coli by R-factor DNA. Proc Natl Acad Sci U S A 69: 2110-2114.

62. Sambrook J, Russell D (2000) Molecular Cloning. A Laboratory Manual. New York, USA: Cold Spring Harbor Laboratory Press.

63. Norheim G, Arne Hoiby E, Caugant DA, Namork E, Tangen T, et al. (2004) Immunogenicity and bactericidal activity in mice of an outer membrane protein vesicle vaccine against Neisseria meningitidis serogroup A disease. Vaccine 22: 2171-2180.

64. de Jonge MI, Vidarsson G, van Dijken HH, Hoogerhout P, van Alphen L, et al. (2003) Functional activity of antibodies against the recombinant OpaJ protein from Neisseria meningitidis. Infect Immun 71: 2331-2340. 
65. Poolman JT, Kriz-Kuzemenska P, Ashton F, Bibb W, Dankert J, et al. (1995) Serotypes and subtypes of Neisseria meningitidis: results of an international study comparing sensitivities and specificities of monoclonal antibodies. Clin Diagn Lab Immunol 2: 69-72.

66. Rosenqvist E, Musacchio A, Aase A, Hoiby EA, Namork E, et al. (1999) Functional activities and epitope specificity of human and murine antibodies against the class 4 outer membrane protein (Rmp) of Neisseria meningitidis. Infect Immun 67: 1267-1276.

67. Welsch JA, Rossi R, Comanducci M, Granoff DM (2004) Protective activity of monoclonal antibodies to genome-derived neisserial antigen 1870, a Neisseria meningitidis candidate vaccine. J Immunol 172: 5606-5615.

68. Wedege E (2001) Immunoblot Analysis of Sera from Patients and Vaccinees. In: Pollard AJ, Maiden MC, editors. Meningococcal Vaccines Methods and Protocols. Totowa, New Jersey: Humana Press Inc. pp. 275-288.

69. Hobbs MM, Malorny B, Prasad P, Morelli G, Kusecek B, et al. (1998) Recombinational reassortment among opa genes from ET-37 complex Neisseria meningitidis isolates of diverse geographical origins. Microbiology 144 (Pt 1): 157-166.

70. Staden R (1996) The Staden sequence analysis package. Mol Biotechnol 5: 233241.
71. Larkin MA, Blackshields G, Brown NP, Chenna R, McGettigan PA, et al. (2007) Clustal W and Clustal X version 2.0. Bioinformatics 23: 2947-2948.

72. Nicholas KB, Nicholas HBJ, Deerfield DWI (1997) GeneDoc: Analysis and Visualization of Genetic Variation. EMBNEW NEWS 4: 14.

73. Moore J, Bailey SE, Benmechernene Z, Tzitzilonis C, Griffiths NJ, et al. (2005) Recognition of saccharides by the OpcA, OpaD, and OpaB outer membrane proteins from Neisseria meningitidis. J Biol Chem 280: 31489-31497.

74. Borrow R, Carlone GM (2001) Serogroup B and C Serum Bactericidal Assays. In: Pollard AJ, Maiden MC, editors. Meningococcal Vaccines Methods and Protocols. Totowa, New Jersey: Humana Press Inc. pp. 289-304.

75. Hobbs MM, Malorny B, Prasad P, Morelli G, Kusecek B, et al. (1998) Recombinational reassortment among opa genes from ET-37 complex Neisseria meningitidis isolates of diverse geographical origins. Microbiology 144 (Pt 1): 157-166.

76. Morelli G, Malorny B, Muller K, Seiler A, Wang JF, et al. (1997) Clonal descent and microevolution of Neisseria meningitidis during 30 years of epidemic spread. Mol Microbiol 25: 1047-1064.

77. Maiden MC, Bygraves JA, Feil E, Morelli G, Russell JE, et al. (1998) Multilocus sequence typing: a portable approach to the identification of clones within populations of pathogenic microorganisms. Proc Natl Acad Sci U S A 95: 3140 3145 